Marquette University

e-Publications@Marquette

College of Communication Faculty Research and

Publications

Communication, College of

$3-1-2006$

Living Our Mission: A Study of University Mission Building

Sarah Bonewits Feldner

Marquette University, sarah.feldner@marquette.edu

Accepted version. Communication Studies, Vol. 57, No. 1 (March 2006), DOI. (C) 2006 Taylor \& Francis (Routledge). Used with permission. 


\title{
Living Our Mission: A Study of University Mission Building
}

\author{
Sarah Bonewits Feldner \\ Purdue University \\ West Lafayette, IN
}

\begin{abstract}
:
At the same time that organizational communication and management scholars are focusing attention on trends of spirituality in the workplace, faith-based organizations are taking up the question of how they might maintain a distinct spiritual identity. For these institutions, communicating mission becomes the defining feature of institutional identity. Explicitly religious organizations provide a venue for understanding the implications of incorporating spirituality in organizational discourse. This empirical study explores a mission-building conference and examines the ways in which communicating a spiritual mission simultaneously enriches and constrains both the individual members and the organizations as a whole.
\end{abstract}

Over 725,000 students attend Catholic colleges and universities (Steinfels, 2003), comprising the largest private educational system in the United States. Over the past 20 years, they have engaged the question of what makes Catholic institutions of higher education distinct from their secular counterparts. Perhaps more to the point, they are interested in determining how they might maintain a decidedly Catholic character amidst changing times. As such these 
institutions have focused efforts on strengthening and affirming Catholic missions and identities. In contrast to the "secular hegemony" that characterizes many organizations, Catholic universities specifically embrace a mission that is rooted in a particular spirituality.

Discourses that surround organizational mission are associated with efforts to infuse spirituality into organizational practice. Most studies within organizational communication have focused on mission in a context that is devoid of spiritual or religious underpinnings. Yet, the term itself denotes and connotes both secular and spiritual meanings. Specific accounts of religious organizations such as Catholic universities expand our understanding of the impact of spiritually based discourses on organizational practice. Considering shifts in policy and the number of people touched by faith-based organizations (e.g., health care, social services) (see Dionne \& Chen, 2001; Steinfels, 2003), it is salient to consider how mission is communicated to organizational members and how mission is reflected in organizational practice. This study examines mission-building efforts of United States Jesuit Catholic universities.

This study extends ongoing conversations about the intersection of spirituality and organizing processes. This study considers faithbased organizations' efforts to maintain a spiritual identity through discourses surrounding organizational mission. This investigation uncovers tensions that emerge when faith-based organizations communicate about mission and members assign meaning to missionbuilding efforts.

\section{Literature Review \& Conceptual Framework}

\section{Spiritual Mission \& Identity of Catholic Higher Education}

As religiously based organizations move into realms often associated with secular organizations, many organizational leaders are examining the characteristics that make them distinct from their secular counterparts and considering how to maintain the religious character of their organizations (Steinfels, 2003). A primary focus for articulating the religious character of an institution is organizational mission. Clearly defining the mission and educating employees about it 
NOT THE PUBLISHED VERSION; this is the author's final, peer-reviewed manuscript. The published version may be accessed by following the link in the citation at the bottom of the page.

is seen as a means by which the religious or mission-based identity may be continued.

Catholic universities are among the religious organizations grappling with questions of religious character and identity. The Catholic Church has been involved in education for centuries. However, Catholic universities face many challenges and changes as they seek to compete intellectually and academically with their secular counterparts. As these universities move to the forefront of higher education in general, discussion amongst Catholic clergy, administrators and scholars often focuses on the degree to which Catholic institutions are fulfilling their faith mission (e.g., Himes, 1992; Lannon, 2001; Reilly, 2003).

Steinfels (2003) addresses this question as he talks about the identity crises facing Catholic higher education in the United States. The onset of identity crises can be explained historically. The original Catholic schools were established to ensure access to quality faithbased education for immigrant Catholics. This mission drove the institutions for some time. As these institutions gained prominence, they sought to be recognized as a part of the intellectual mainstream. Focus shifted to academic excellence (Gleason, 1995). Even with this shift, Catholic institutions maintained a strong Catholic character through the institutions' sponsoring religious orders. However, the numbers of religious vocations are declining. Many institutions have been forced to give authority to lay people. Minus the literal presence of religious men and women, institutions have realized that they must seriously consider what makes Catholic institutions-Catholic. For many institutions, the answer lies in a renewed focus on mission (Steinfels, 2003). Mission, for these institutions, represents an expressed spirituality (Konz \& Ryan, 1999).

This study focuses specifically on Jesuit universities. The rationale for this focus is twofold. First, the Jesuit order has a longstanding history of establishing and maintaining colleges and universities worldwide and is the single most recognizable branch of Catholic higher education in the United States (Lonsdale, 2003; Steinfels, 2004). Second, this particular network of institutions is actively engaged in efforts to refocus attention to mission and to communicate this mission to key stakeholder groups. 
The history of Jesuit education has shaped contemporary understanding of Jesuit education. Key tenets of Ignatian spirituality serve as the basis for Jesuit education. Gray (2003) summarizes the Ignatian mission as a spirituality that is about "people who want to work in ways that help other people" (p. 1). How Saint Ignatius went about deciding how one might be called by God is found in the spiritual exercises, which are a series of reflections that ask individuals to consider what God calls them to do (Gray, 2003; Lonsdale, 2003).

Early in their history, members of the Society of Jesus determined that one way to fulfill their mission/calling was to educate. Jesuit education is rooted in a liberal arts curriculum coupled with spiritual development. Jesuit education is framed as education for the whole person (spiritual and moral) (Laczniak, 2004). The Ignatian principle of helping manifests itself in education that is centered on reflection, social justice, finding God in all things, and cura personalis (care for the whole person) (Board of the Jesuit Conference, 2002; Kolvenbach, 2001).

Initially, Jesuit brothers and priests were the primary instructors and administrators at these institutions. They were able to teach students principles of Jesuit spirituality. Today, the numbers of Jesuits are dwindling. It is projected that in 10 to 15 years, there will 12 Jesuits for every Jesuit college in the United States (Purcell, 2004). These institutions' administrations must find other ways to maintain the Jesuit character of their institutions. Jesuit colleges and universities have implemented programs designed to educate lay people in Jesuit basics.

The ways in which these institutions go about this process are diverse and yet common themes tie these efforts together. Across Jesuit campuses, there are a variety of programs targeting faculty and staff to focus on the message of Jesuit mission. These programs include orientation programs and seminars. Faculty and staff are invited to participate in mission lunches, retreats, and, in some cases, spiritual exercises. Other institutions have developed publications such as Xavier University's "Do You Walk Ignatian?" (Mooney, 2002), which serves as a primer on basic Jesuit vocabulary and tradition. Most institutions have established administrative offices or positions focused specifically on mission and identity. Although the program formats and

Communication Studies, Vol. 57, No. 1 (March 2006): pg. 67-85. DOI. This article is @ Taylor \& Francis (Routledge) and permission has been granted for this version to appear in e-Publications@Marquette. Taylor \& Francis (Routledge) does not grant permission for this article to be further copied/distributed or hosted elsewhere without the express permission from Taylor \& Francis (Routledge). 
particular mission statements of Jesuit institutions are not identical, efforts to focus on mission share Ignatian roots. The result of this shared foundation is an emergence of common Ignatian themes in the primary discourse about mission (e.g., men and women for others, caring for the whole person, and acting for the glory of God).

A renewed focus on mission and identity reveals complexity because the mission of these institutions is in fact to accomplish a spiritual mission. That is, the purpose of Catholic higher education is to fulfill the faith mission of the church. For Jesuit universities, mission entails: (a) the organization's purpose and (b) the faith calling of the institution as it has been historically framed by the Catholic Church.

\section{A Conceptual Framework for Communicating a Spiritual Mission}

Although many organizations spend time developing and communicating their missions, to understand mission in the context of a spiritually based organization requires a more complex conceptual framework than that which is currently offered by organizational communication and organizational development scholars. Thus, I offer a framework based on the intersection of work addressing spirituality in organizations and studies of organizational mission.

\section{Spirituality in Organizations}

Chalofsky (2003), Herman and Gioa (1998), and Cavanaugh, Hanson, Hanson, and Hinojosa (2001) argue that infusing spirituality into the workplace provides deeper meaning for employees. In management literature, spirituality is defined as a search or desire for finding meaning and purpose in organizational life (Leigh, 1997; Mitroff \& Denton, 1999). Alternately, spirituality represents the relationship between human experience and the transcendent (Konz \& Ryan, 1999). Although spirituality and religion are distinct concepts, for some organizations, spirituality suggests an affiliation with a specific religion. Religion is associated with a particular institutional structure, rituals, and specific dogma (McCormick, 1994). Every religion carries with it a particular spirituality. 
The secular understanding of spirituality becomes intertwined with religion in faith-based organizations. Faith-based organizations are associated with a formal religion (Cnaan \& Boddie, 2002). All of these organizations seek to fulfill a secular purpose while maintaining a distinct faith-based/religious identity. As in secular organizations, spirituality for a faith-based organization involves a search for meaning and deeper understanding of human experience; however, the difference is that faith-based organizations find answers to that search in a specific faith tradition. For example, Sheldrake (2003) suggests spirituality is concerned with human experience and values. Christian spirituality views human experience through a belief in the Gospels, Jesus Christ, and the Holy Spirit. Although distinctions between spirituality within secular and faith-based organizations are important, the parallels suggest that faith-based organizations can benefit from and contribute to a larger understanding of spirituality in organizations.

Much of the work that focuses on spirituality in the workplace is descriptive, based on interviews with employees and managers. The focus of this work is defining spirituality and providing a rationale for including spirituality in organizational life. Beyond studies establishing spirituality as a catalyst for organizational change, work is needed that explores how organizations can foster a culture of spirituality. Konz and Ryan (1999) highlight the idea that organizations who seek to identify themselves as spiritual must find ways to communicate their spirituality in ways that have meaning for all organizational members. Current discussions of spirituality focus on organizational mission as a primary means for accomplishing that.

\section{Organizational Mission}

Organizational leaders and scholars alike often devote a great deal of time and energy to developing and implementing organizational mission statements. Yet, concrete definitions of mission are relatively scarce. At its most basic level mission refers to the purpose of an organization (Fairhurst, 1993), the core of what the organization does (Bergquist, 1993), or a reference point for organization members (Fairhurst, Jordan, \& Neuwirth, 1997). Organizational development researchers contrast an organization's mission with its vision. Mission defines a purpose and identifies 
features that differentiate one organization from other organizations and explains why the organization exists (Lipton, 1996; Strong, 1997). Mission coupled with strategy and culture creates an organization's vision (Lipton, 1996). Vision looks forward and provides an image for what the organization will be in the future.

Organizational mission statements reflect the culture and ideology driving an organization (Swales \& Rogers, 1995). The mission statement expresses common interests shared by organizational members, fosters commitment to the organization and cultivates member identification with the organization (Bergquist, 1993; Cheney \& Christensen, 2001; Swales \& Rogers, 1995). Finally, mission statements legitimate the existence of the organization and justify its operation (Connell \& Galasinski, 1998). Because a mission statement is tied closely to an organization's culture, the mission statement gives meaning to the organization itself.

The majority of studies of organizational mission emphasize the communication of the mission statement. Although a formalized mission statement is a primary discourse for communicating an organization's mission, organizations use other means to articulate their missions. Trice and Beyer (1985) provide an account of the significance of organizational ritual for understanding organizational culture. Rosen's (1988) ethnographic account of a company Christmas party provides an exemplar of the ways in which organizational events are a means of making the ideology of an organization visible. Ideology, in this sense, is a basic sense of what the organization is and what it is about. Thus, organizational ritual is a means of communicating and maintaining a particular sense of the organization.

Rothenbuhler $(1998,2006)$ offers a perspective on ritual that adopts a decidedly communicative focus. Rothenbuhler (1998) argues that ritual is "the voluntary performance of appropriately patterned behavior to symbolically effect or participate in the serious life" ( $p$. 27). Participants in ritual accomplish significant social purposes through the use of symbols. The focus on the serious life suggests that in all social life some ideas and activities are seen to be more important and more significant. In this way, organizational practices that focus on the core values and purposes of an organization should be seen as a particular form of ritual. Despite the linkages between 
ritual, communication, and organizational life, few scholars have used ritual as an analytical lens to study organizational practice (Rothenbuhler, 1998). More to the point, studies of organizational mission have failed to look at organizational events and rituals as a means of communicating an organization's purpose. Yet, many organizations have seminars, conferences, and events to communicate the purpose and identity of the organization to members. For example, several major consulting firms have weekend long training sessions that focus on the work done by their firms and aimed at distinguishing their projects from competitors. Adopting Rothenbuhler's theoretical frame, I argue that studies of mission should consider the ways organizational ritual functions as a means of communicating mission.

\section{Research Questions}

Organizational mission is a construct traditionally studied from a secular vantage point. However, some organizations view mission as a means of infusing spirituality into practice. Mission, in this sense, provides a foundation for a search for greater meaning and exploration of human experience. More specifically, faith-based organizations seek to define themselves as organizations that fulfill a specific purpose while responding to a particular religious tradition. Few studies examine the specific discourses and communication practices that foster spirituality in the workplace, and research on mission remains largely descriptive and narrowly focused on mission statements. A broader exploration of mission provides a means for understanding both spirituality in organizations and organizational mission.

Although it is clear from commentary on Jesuit higher education that identity and mission are key concerns, little focused research explores how efforts to communicate a particular mission are meaningful for organizational members. This study seeks to fill this void by asking the following research question:

RQ1: How do organizational members make sense of and assign meaning to their institutions' mission building efforts? 
NOT THE PUBLISHED VERSION; this is the author's final, peer-reviewed manuscript. The published version may be accessed by following the link in the citation at the bottom of the page.

\section{Method}

\section{Context \& Participants}

The focal point of this study is a three-day conference held in the summer of 2004 on a Midwestern Jesuit campus. The conference was the third in a series and grounded on the recognition that changing demographics necessitated serious consideration of the direction of Jesuit institutions. Further, leaders of Jesuit institutions recognized that as a body they had a great deal in common and a number of resources that could be shared. This conference brought together 489 delegates from 12 Jesuit institutions.

The theme of the conference was "Companions in Mission." The central focus of the conference was the guest speakers. The first session of speakers included two presidents of Jesuit institutions who were not Jesuits. One of these speakers stood out in that he was not a member of any religious order. He spoke of how his experience with the spiritual exercises shaped his leadership style and helped to chart his course as a leader. The next day featured a panel of speakers that included a faculty member, a student, and an alumna. Each spoke of how their work connected to the Jesuit mission. The alum focused on his work with prisoners, and the faculty member spoke of her program that trained healthcare workers to care for AIDS patients in Africa. The student told her story of being "broken" while spending a semester working with the poor in Mexico. Following this panel presentation was a powerful speech given by a Jesuit from the projects in Los Angeles who devoted his life to putting gang members to work and serving the poor in the barrio. He told stories of tragic loss and of hope. He emphasized his belief that every individual should stand where Jesus would stand, with the people who have no hope.

A total of 26 in-depth interviews were conducted with conference attendees and analyzed for this study. Of the 26 interviewees, 9 were male, and 17 were female; 13 identified themselves as Catholic; 6 identified themselves as non-Catholic, and the remaining 7 did not specify their spiritual background. All 26 of these interviewees worked at one of the institutions represented at the conference. Their length ofservice to their respective institutions ranged from 1 to 32 years. The positions held by these participants 
included: professor (assistant and associate), staff psychologist, admissions counselor, director of university ministry, director of alumni affairs, senior grant writer, department chair, dean, administrative assistant, business services manager, and Vice President of Academic Services. The range of positions and backgrounds of these interview participants is representative of the delegates who attended the conference.

\section{Procedures}

\section{Data collection}

After the conference was completed, all 489 conference participants were contacted via E-mail and were invited to participate in these interviews. All who volunteered for these interviews were selected. Volunteers were interviewed either in person ( 9 interviews) or via telephone (17 interviews). The interview protocol was developed based on my background research on organizational mission, Jesuit and Catholic mission, and my review of fieldnotes from the conference. These interviews focused on participant responses to the conference, their understanding of its purposes, and their thoughts about the mission of their institution. The conference experience was the focal point of the interviews as it was the experience shared by all participants. However, as the conference itself was aimed at addressing issues of mission, the interviews included questions about the missions of the institutions generally. Each interview lasted between 45-90 minutes. Each interview was transcribed using conventions used by Tracy and Baratz (1993) where the focus of analysis is the content of what is said and not the details of the interaction (e.g., pauses, talk overs). Transcription resulted in approximately 300 single-spaced typed pages. To protect participant confidentiality, I changed all names, places, and identifying information.

I attended the conference as a delegate and participated fully in all meetings and conference events. I did not know any of the interview participants prior to conducting this study. My dual role as participant and researcher does influence my interpretation of the events. First, I heard all of the speakers and participated in reflection sessions, which provided me with important context for the study. My 
participation further impacted the research process as it gave me a shared experience with the interview participants. This shared experience facilitated rapport building and allowed me to visualize the events referenced in the participant comments. More to the point, I was able to ask more specific questions about the speakers and events.

\section{Data Analysis}

To analyze the data, I used constant comparative methods (Glaser \& Strauss, 1967; Lindlof, 1995). I read through fieldnotes and interview transcripts in their entirety looking for themes and recurring issues as they organized around the specific focus of this study. I then reread the transcripts seeking to identify relationships and patterns within themes. Finally, I compared specific incidents within the same theme to determine "goodness of fit" (Lindlof, 1995, p. 223). Once I addressed issues surrounding the research focus, I identified two overarching concerns. First, participants find the mission simultaneously inspiring and overwhelming. Second; participants identify a tension between the message of the mission and the actions of the organization. The results presented here are an interpretation of these concerns.

\section{Results and Interpretations}

During the interviews, the participants repeated and echoed key themes and ideas from the conference. Although the conference effectively transmitted slogans and phrases that express the mission, these interviews suggest that the conference also shifted responsibility for upholding the mission to the employees. This effort to communicate a mission to individuals served to motivate them to rise to meet the high expectations held in the mission. At the same time, the emphasis on mission elevated expectations for the organizations' actions. Thus, my analysis reveals that focus on a spiritually based mission creates tensions on both an individual and an organizational level. 


\section{Called to Do More: Rising to Meet Expectations}

The participants' comments suggest that the missions of their institutions provide an avenue for blending spiritual selves with work selves. An overarching sentiment that they shared is that the conference inspired them and affirmed their desire to continue to find ways that they can better live out the mission in their jobs. These individuals responded exclusively to the religious dimension of the mission. They expressed freedom to talk about their faith, but this freedom obligates them to even greater service to the institution.

When speaking generally about the missions of their institutions, the efforts of the institutions seem to be having an impact. Although a few respondents indicated that they had never heard of the mission, most indicated that you learned the mission through "osmosis." Several participants commented that the mission is communicated constantly through slogans, banners, and repeated phrases. When explaining how they learned about the mission the prevailing sentiment was that at a Jesuit university the mission was simply a part of the culture. One delegate captured this sentiment as he spoke about how people find out about the mission:

It's just sort of there. Not in your face, it's very subtle, it's the way people are, it's the way people do business and you, you just sort of get infected by it. It's sort of a mystical experience ... It's good, what I mean is you don't go out and have a lecture on Jesuit U's mission. Now they go over that during orientation but it's just sort of around you .... it's very subliminal and you just come to, to an implicit understanding that that's how you conduct yourself on a day to day basis. Some certainly have a stronger buy-in than others you know I don't consider myself to be the Jesuit $U$ poster child for how to conduct yourself but I think I do a pretty decent job at it. I think most people do. But you just do it. You do it because everybody else is doing it. Because you know you'd look funny by not doing it. Like what's the matter with you, you're not acting like everybody else?

Beyond any specific focus on mission, the perspective shared by participants in this study illustrates Gidden's (1984) theory of structuration. For Giddens, social structure represents social norms 
and routine practices. The theory of structuration suggests that these social structures shape communication while at the same time communication practice shapes social structure. In this instance, the Jesuit culture or social structure is constructed and reconstructed through repeated interactions and discourse that highlight key elements of Ignatian spirituality.

Throughout the interviews, the participants suggested that working for a Jesuit Catholic institution provided a freedom and acceptance that they would not expect to find in other places. For many this freedom was the ability to openly discuss issues of spirituality. As several of the interviewees expressed, the mission allows "the freedom to discuss your faith and no one will look at you funny;" "Jesuit education is not apologizing for talking about God." Another suggested that the mission allowed individuals "to articulate a common effort to say that we are really doing God's work here. Let's not forget it in fact let's say it more clearly." This freedom to openly express religious views is tied to an ability "to talk about a purpose driven life and find meaning in my work." One interviewee suggested that the mission:

really facilitates addressing people as whole people and talking about their religious views and their values and beliefs and their spirituality. You don't have to couch it in something else, and so it really facilitates you being able to work with the whole person.

The focus on the whole person and serving God not only expresses a sentiment that resonates with this individual it also echoes the slogans and phrases used by these institutions to express the key tenets of Ignatian spirituality. As such, the delegates' comments suggest that these slogans do serve a useful function for these institutions. Further, these delegates' comments indicate that the focus on mission allows them a freedom to pursue that wholeness and affirms their belief that they are doing meaningful work. Rather than being seen as a burden, the focus on mission allows for an exploration of the deeper meanings of life (Barker, 2004).

Beyond providing for religious expression, conferences such as "Companions in Mission" serve to direct attention to the mission and affirm its purpose in the institution. As two participants commented, 
the conference "refocused people more toward the mission" and made the mission "more real." The sessions focused specifically on mission were seen as a means by which participants were able to "really stop and think about what that [the slogans and buzzwords of mission] meant. Rather than just bandy those words about." When asked if this refocusing was necessary, the individual responded, "Yeah, because when you take any job really, and you get entrenched in the job and the day-to-day routine and you kind of sometimes lose sight of the bigger picture and need to kind of be reenergized." For these delegates, the conference and its message were incredibly reenergizing as they commonly spoke of the experience as motivating, inspiring, and affirming-even "contagious."

When asked for a message that stood out for them the most from the conference, the delegates in this study most often cited the Jesuit who worked with gang members. He told stories of children shot in gang warfare crossfire and spoke of the need for kinship in spite of the violence in these streets. The impact of the message and overarching theme cited by these delegates was to call them to do more. Whether they recalled this Jesuit's presentation or the words of the president of a Jesuit institution as a focal point, the impact of hearing these messages is captured in responses such as the delegate who said, "We have more of a responsibility for [the] togetherness of the Jesuit community and that we have a greater function of service outside our own communities. So in that regard, others [come] first." When translating these messages into job expectations, another delegate explained that she believed she is expected to:

... do the best job I can, to relate to others in a caring and compassionate way, to integrate myself into the community through volunteering to help someone. We're supposed to be able to accomplish our job task but I think they're asking us to take it further.

Still another commented on the impact of the conference, "I got it by osmosis ...the 'it' that I got was somewhat of the history of the Jesuits and also maybe that sense of what you want to do in your job ... certainly gives you pause to say that you could do more on your campus." 
This notion that one could do more was an overriding sentiment of the delegates as a majority suggested that the message of the conference made them more aware of the many things that they could be doing to further the mission on their campuses and in their community. One delegate explained her understanding of the purpose of the conference by saying it meant:

Push that envelope and make a connection with the world, whatever your world is or whatever your given position happens to be ... One person can make the world a better place and we all need to push ourselves to make that connection outside of ourselves.

Although this expectation to do more is certainly a noble calling, as I listened to these participants speak, I was also struck by the extent to which the expectations that they take away are quite high or as one delegate told me-"almost overwhelming." Thus, a drawback of these inspiring messages is they lead delegates to translate the message into one that tells them that they are not doing enough: "I think they (the speakers) made you feel like, wow, I have to do my fair share because look what other people are doing." One delegate explained that after hearing the stories of service that "the whole next day I was thinking I didn't do anything with my life compared with what she's done." The danger as one delegate commented is that "everyone walks away like, wow, oh god, I can't do things like that and that isn't the point at all." Yet, this was a common response. In one of the more striking reflections, a delegate explained:

To hear those stories and we think that we have our own problems you know and it made me ashamed because I think of my problems in light of these real problems that people deal with ... I said before that I almost felt unworthy or worthless after hearing him.

In considering the responses of these delegates, it is important to recall that for many, the mission of this institution is the mission of their faith. This layering, combined with the introduction of charismatic and awe-inspiring speakers makes for a very powerful message that is difficult to avoid. In this case, one could argue that the spiritual nature of the mission itself solidifies the position of these delegates as outside 
the hierarchy of power (as non-Jesuits) and yet they speak in terms of individual responsibility for "doing more" to maintain the Jesuit community. At the same time that the discourse about the mission creates pressure and expectation for these delegates, the infusion of spirituality into the mission does have benefits for these employees in that it provides for a meaningful workspace that many suggest they desire.

The data suggest a tension in seeking to draw in employees as "companions" in mission. The university administrators seek to prepare these employees to take over as those who may someday run the institutions. In this, they are successful. The interview participants consistently reflected a desire to maintain the spiritual focus of Jesuit institutions. Yet, at the same time, the powerful and emotional way in which institutions communicate this aim leads many delegates to believe that they can never do enough to reach the heights of where they should be. In focusing on a message of mission that is powerful, compelling, and spiritual, communication about mission inadvertently creates a tension. These delegates embrace the significant spiritual purpose of the organization, yet they feel unable to live up to the greatness embodied by this mission.

Communication about mission is affirming in that it supports these individuals' desires to openly express spiritual comments. At the same time, these messages are disconfirming as they suggest that these employees' efforts are insignificant and inadequate when compared to the mission work of others. The challenge then lies in communicating a religious mission that finds the balance between empowering employees to embrace the spiritual mission of the organization without setting expectations so high that they overwhelm (or overwork) employees.

\section{Raising Expectations: Identifying Organizational Inconsistency}

Even while taking individual responsibility for mission, these delegates do recognize gaps between their understanding of mission and the ways that their institutions operate. As Fairhurst (1993) highlights, organizational members can see inconsistencies between how mission is communicated and the practices of the organization. In 
this study, I found that the promotion of the religious mission of the institution creates a tension that is just as problematic on an organizational level as it is for the individuals. In the eyes of these employees, just as the mission raises expectations for them, so too are expectations raised for the institution itself.

The delegates recognize the extent to which the university leaders themselves do not always live up to the Jesuit ideals set forth in their institutional mission statements. As one delegate commented, "we've got our scandals and some administrators who do not tell the truth." Another said quite directly that he does not feel that mission is what drives the school.

Throughout the interviews, delegates commented on the degree to which they felt their institutional leaders did not live out the mission when it came to handling issues such as layoffs, raises, and hiring. One of the Jesuit ideals or slogans that was most commonly mentioned throughout the interviews was the idea of cura personalis. This is a phrase that means to care for the whole person. These delegates embraced this sentiment; however, they did not always feel this perspective was used by their institutions. One administrative assistant expressed her frustration commenting "while there is some recognition for employees, sometimes I just want to shake the school." The vice president expressed a concern over the ways in which people get laid off. She explained she felt the administration was not looking at things from the perspective of cura personalis because they do not look for other cuts so that the interests of individuals are protected. Finally, a delegate pointed to the lack of social justice in the actions of her institution:

.. now it doesn't seem to matter as much because people are happy to be here for the most part but there are inequities concerning who gets paid what-like I don't think we pay our grounds crew enough and also we go about congratulating ourselves about our community service but we haven't hardly scratched the surface.

The latter part of her comment taps into a second concern, which is the extent to which the institutional members as a whole live out the social justice mission of their institutions. Many Jesuit 
institutions were consciously placed within urban environments so that they could fulfill the mission of being out in the community. Yet, many of them have fences surrounding them or they are buying up property without regard to who might be displaced. Two different people from two different campuses captured this sentiment. The first said:

We are smack dab in the middle of the city and we never go outside our iron gates and I think that this is really one of our weaknesses-we stay in here and congratulate one another and it's hard to get outside the gate unless you are driving home.

The second observed that:

Although the institution may articulate values that are Christian and Catholic ... we're buying up territory as best we can in order to increase the perimeter of the university and keep people who might bother our students out of the way. That makes sense from a practical point of view, but are we really reaching out to the community and serving them as well as we could? Probably not.

These comments speak for themselves in terms of pointing out the break between what the institution members say about their purposes and what institution members do.

These delegates acknowledge practical concerns faced by their institutions, but they expect their institutions' leadership to make decisions that are rooted in the values espoused by the mission. One delegate talked about her administration selling the university's hospital. People charged that this was not in keeping with the mission of the university. She continued by saying that, "the mission is not necessarily saying whether or not you should sell that hospital, but how you should handle it." The issue of how decisions get made and how things get handled is central for these delegates. They told stories of how messages communicated at the conference led them to consider how to approach their decisions from a mission-based perspective. As a result, these respondents expect institutional leaders to engage in the same reflective process.

The irony here is that the delegates have "bought in" to the Jesuit mission and ideals. Consequently, they expect their institutional leadership to do the same. Milliman, Ferguson, Trickett, and Condemi 
(1999) caution that organizations cannot simply incorporate spirituality into a mission statement, it must exist in practice. The problem for the institutions is that they are faced with the practical side of running a university. One delegate described the tension as he said, "the university is still a business, and it needs to run that way." Yet another commented:

I think that we have an unhappy blend sometimes (between the way the university operates and its mission) of wanting things and yet the practicality of it, it's more difficult than it sounds at least here at this university a lot of our concerns are driven by this as a business as well as a university ... we've become leaner and meaner and that's not a good thing... we need to get back to those things that really assist our neighbors.

These comments point to the fact that religious-based institutions face a challenge that is shared by their secular counterparts-the influx of corporate pressures and business realities into educational endeavors. The corporatization of higher education is well documented (e.g., Deetz, 1992; Giroux, 1999). The difficulty that emerges in the context of a religious mission is that the organization's stakeholders see the religious mission as providing a standard behavior for the institution that is morally based. It is one thing for a public institution to veer from its educational course to pursue a business mentality; it is an entirely different issue for a religious institution to act in ways not in keeping with God's call. One delegate's discussion of the lack of a maternity leave policy addressed how the Jesuit mission leads to greater expectations:

I do have expectations that there is going to be a certain level of care here and I think that fueled a lot of my frustration with the maternity leave...I have an expectation that you know if you say this is who you are than this needs to be who you are in... in every area....and that's like I said I kind of saw Jesuit $U$ missing that mark there.

It is significant to note here the extent to which the institutions' own rhetoric entraps them. In many ways, the leaders of Jesuit institutions create an untenable position. As they actively promote the institution's religious mission, they find themselves in a place where 
the demands become more than they can provide in terms of living out mission in all aspects of university life.

The tension on an organizational level emerges as the official rhetoric of the university makes links between the spiritual purpose of the institution and the academic purpose of educating students. The source of this tension lies in the fact that the concept of mission itself implies dual purposes that are not always commensurate. Mission, in a spiritual sense, refers to the propagation of a particular faith tradition. However, mission, in a secular sense, denotes the purpose of the organization. Jesuit universities have the purpose of propagating the faith and the purpose of educating students. At times, these two senses of mission are at odds with one another. As university administrators seek to operate the university in ways that allow them to meet the educational needs of students, they fall short of meeting the promise of the faith mission of the institution. Because universities serve an academic purpose, one might expect discussions of mission to address this aspect of university practice. However, the participants in this study focused almost exclusively on the spiritual aspects of the mission.

The challenge then is to determine ways in which academic and management decisions might be framed within the religious notion of mission or to determine ways in which the more secular purpose of the institution might be brought into discussions of spirituality. In part, it seems that the difficulty faced by these institutions lies in the fact that they keep the mission as a calling separate from the academic mission. It would be beneficial to bring these two senses of mission together into a single identifying force. Currently, the public communication of the spiritual identity of Jesuit institutions is primarily focused on the religious calling to the exclusion of the practicality of running an institution in contemporary society.

\section{Discussion}

The "Companions in Mission" conference served as the impetus for delegates to reflect on organizational mission and their individual roles in the organization. In this, the conference is an effective model for how organizations might successfully communicate the content of a mission. However, this analysis of mission within a faith-based context 
reveals a number of interesting issues. Most significant is the emergence of tensions that impact both individuals and organizations. I argue that paradox is a useful construct for understanding how organizational members make sense of and assign meaning to their institutions' mission-building efforts.

\section{Theoretical Implications}

Several scholars have taken up tension, contradiction, and paradox to examine organizational interactions (e.g., Tretheway \& Ashcraft, 2004; Stohl \& Cheney, 2001; Turner, 2004). Tretheway and Ashcraft (2004) argue that these tensions or organizational irrationality are common to all organizations. Rather than viewing contradiction as negative, this line of work suggests that this is a place where useful and applicable meaning might be found (Tracy, 2004; Turner, 2004). Stohl and Cheney (2001) provide an extensive analysis of paradoxes, contradictions, and irony that is particularly useful in examining this case. Paradox represents a tension in which "in the pursuit of one goal, the pursuit of another competing goal enters the situation so as to undermine the first pursuit" (p. 354). Paradoxes are those instances in which organizational efforts appear to work against themselves.

In looking at Jesuit institutions efforts to communicate identity through emphasis on mission, the paradoxes that emerge represent pragmatic paradoxes, which are those that must be understood in the context of interaction (Stohl \& Cheney, 2001). The paradox in this context is split between the level of the individual and the organization.

First, on the individual level, as these Jesuit institutions lead members to internalize a sense of mission, they simultaneously suggest that these individuals are somehow unworthy or falling short of institutional goals. The paradox parallels the paradox of naming identified by Turner (2004) in her study of midwifery. In this, midwives are not physicians but yet they are called to function as doctors. Here, employees at Jesuit institutions are reminded that they are not Jesuits, but yet they feel called to carry on the tradition of the Jesuit institutions. 
The individuals in this study embrace the inclusion of a spiritual mission, seeing this as a greater freedom in their work. Yet, this freedom is limiting. Clair's (1994) self-contained opposite looks at acts of resistance that are simultaneously oppressive. In this case, the expressed resistance is not direct resistance to institutional administration but rather resistance to the larger societal belief that spirituality is a private matter. This resistance though does function as a form of control as these delegates who see themselves as "on board with mission" feel obligated to meet the high expectations set forth by the institutions' faith missions.

On an institutional level, the paradox is one of emphasizing the spiritually based mission of the organization to inspire members to rise to higher expectations and, thus, ensure the continued success of the institution. However, these practices simultaneous raise the expectations for the institution making it difficult for them to continue toward academic excellence while maintaining the faith mission of the university. This parallels the paradox of adaptation (Stohl \& Cheney, 2001). In this paradox, the organization seeks to maintain its identifying characteristics while adapting to organizational surroundings. Jesuit university emphasis on institutional mission reflects an interest in maintaining the Jesuit Catholic character of these institutions. Yet, these efforts seem to undermine efforts to develop a strong academic mission.

The identification of these paradoxes demonstrates that contradiction is not a sign of dysfunctional organizations. I argue that these Jesuit institutions have been very successful in their attempts to communicate a strong sense of mission. However, this success is not without limitations. These findings suggest that organizational paradoxes emerge in the absence of active resistance or problematic communication. Further, paradox is an important construct for considering the implications of the infusion of spirituality in organizations. Often when considering spirituality, focus is given to obstacles and limitations for celebrating spirituality in organizations. This case suggests that there are other questions to be considered, namely that successes in incorporating spirituality can lead to limitations in other areas. This finding although rooted in the experience of Jesuit Catholic institutions has relevance for other faithbased organizations as well as secular organizations seeking to 
explicitly embrace spirituality. The paradoxes that reveal themselves here are not exclusively tied to the Catholic faith; rather, they are rooted in the emotion and power individuals in these organizations attach to religious beliefs.

\section{Limitations}

There are limitations to this study. First, the participants in this study represent a select group of individuals. These are the individuals who "buy into" the mission. Yet there are a number of faculty, staff, and administrators who choose not to participate in these missionbuilding programs. In fact, many delegates specifically cited the faculty as a group that was less likely to be interested in these issues. Future study in this area would be enhanced by looking at both those who identify with the mission and those who do not. Second, this analysis does not incorporate a strong sense of power. One might conclude that invoking a religious sense of mission operates as a prime example of deep structure control. I do believe that the conference acts in significant ways as a form of discursive closure (Deetz, 1992) in that couching rationales in terms of a religious calling makes it difficult to challenge the meaning of the mission. Further examination of the power dimensions in these communication processes is warrante

\section{Pragmatic Implications}

Stohl and Cheney (2001) argue that "paradox delimits options for participants in a system, particularly if there is little awareness of what is happening or if members are unable to comment on it" ( $p$. 352). On a pragmatic level, all members of Jesuit institutions would benefit from open discussion of the paradoxes that emerge when pursuing the dual senses of mission. This study provides an avenue for identifying contradiction and considering useful responses.

To address paradox, Stohl and Cheney (2001) suggested several strategies that inform this case. First, the strategy of loyalty, rededication, and adaptation entails maintaining focus on shared core values while working to improve the organization. This stance would be particularly useful for the delegates. They remain committed to the Jesuit principles, but rather than see the contradictions as something they must accept, they can work to make change. One strategy for 
enacting this change is voice, which speaks to both levels of paradox. As individuals seek to participate in decision making, institutions should consider how to facilitate broad participation in decision making that addresses not only the spiritual mission but also the academic mission. In part, the difficulty that arises in this situation is that communication of mission in this sense focuses on spiritual mission to the exclusion of academic mission. Reframing academic decisions within the context of the spiritual mission can provide avenues for living within this paradox.

\section{Conclusion}

It is quite fitting that the closing ceremony at this conference included a missioning ceremony in which delegates were sent forth to continue seeking ways to live the mission on their campuses. In many ways, this analysis suggests a need to continue looking at the role of faith-based organizations within society and considers ways in which the mission of mission has implications for individuals and organizations. The mission of organizational communication researchers might include seeking ways of expanding understanding of the concept itself.

\section{References}

1. Barker, J. (2004). Forum introduction. Management Communication Quarterly, 17, 586-588.

2. Bergquist, W. (1993). The postmodern organization. San Francisco: JosseyBass.

3. Board of the Jesuit Conference. (2002, May). Communal reflection on the Jesuit mission in higher education: A way of proceeding. Washington, D.C.: Society of Jesus in the United States.

4. Cavanaugh, G., Hanson, B., Hanson, K., \& Hinojosa, J. (2001, March). Toward a spirituality for the contemporary organization: Implications for work, family and society. Paper presented at the Bridging the Gap Between Spirituality and Work Conference, Santa Clara, CA.

5. Chalofsky, N. (2003). An emerging construct for meaningful work. Human Resources Development International, 6(1), 69-83. 
6. Cheney, G., \& Christensen, L. T. (2001). Organizational identity: Linkages between internal and external communication. In F. M. Jablin \& L. L. Putnam (Eds.), The New handbook of organizational communication (pp. 231-269). Thousand Oaks, CA: Sage.

7. Clair, R. P. (1994). Resistance and oppression as a self-contained opposite: An organizational communication analysis of one man's story of sexual harassment. Western Journal of Communication, 58, 235-262.

8. Cnaan, R. A., \& Boddie, S. C. (2002). Charitable choice and faith-based welfare: A call for social work. Social Work, 47, 224-235.

9. Connell, 1., \& Galasinski, D. (1998). Academic mission statements: An exercise in negotiation. Discourse \& Society, 9, 457-479.

10. Deetz, S. (1992). Democracy in an age of corporate colonization: Developments in communication and politics in everyday life. Albany: State University of New York Press.

11. Dionne Jr., E. J., \& Chen, M. H. (2001). When the sacred meets the civic: An introduction. In E. J. Dionne, Jr. \& M. H. Chen (Eds.), Sacred places, civic purposes: Should government help faith-based charity (pp. 1-18). Washington, D.C.: Brookings Institution Press.

12. Fairhurst, G. T. (1993). Echoes of the vision: When the rest of the organization talks Total Quality. Management Communication Quarterly, 6, 331-371.

13. Fairhurst, G. T., Jordan, J. M., \& Neuwirth, K. (1997). Why are we here?: Managing the meaning of an organizational mission statement. Journal of Applied Communication Research, 25, 243-263.

14. Giddens, A. (1984). The constitution of society: Outline of the theory ofstructure. Berkeley: University of California Press.

15. Giroux, H. A. (1999). Corporate culture and the attack on higher education and public schooling. Bloomington, IN: Phi Delta Kappa Educational Foundation.

16. Glaser, B., \& Strauss, A. (1967). The discovery of grounded theory. Hawthorne, NY: Aldine. permission has been granted for this version to appear in e-Publications@Marquette. Taylor \& Francis (Routledge) does not grant permission for this article to be further copied/distributed or hosted elsewhere without the express permission from Taylor \& Francis (Routledge). 
NOT THE PUBLISHED VERSION; this is the author's final, peer-reviewed manuscript. The published version may be accessed by following the link in the citation at the bottom of the page.

17. Gleason, P. (1995). Contending with modernity: Catholic higher education in the twentieth century. New York: Oxford University Press.

18. Gray, H. (2003, Summer). In all things. In All Things: A Jesuit Journal of the Social Apostolate, 1-2.

19. Herman, R. E., \& Gioa, J. L. (1998). Making work meaningful: Secrets of the future focused corporation. The Futurist, 32(9), 24-38.

20. Himes, M. J. (1992). Catholicism as integral humanism: Christian participation in pluralistic moral education. In F. C. Power \& D. K. Lapsley (Eds.), The challenge of pluralism: Education, politics and values (pp. 117-139). Notre Dame, IN: University of Notre Dame Press.

21. Kolvenbach, P. (2001). The service of faith and the promotion of justice in American Jesuit higher education. America Magazine, 184(3), 8-12.

22. Konz, G. N. P., \& Ryan, F. X. (1999). Maintaining an organizational spirituality: No easy task. Journal of Organizational Change, 12, 200210.

23. Laczniak, G. R. (2004, Spring). Developing the brand equity of Jesuit higher education. Conversations on Jesuit Higher Education, 25, 3-11.

24. Lannon, T. R. (2001, Fall). The role of presidents promoting Catholic identity at Jesuit universities. Conversations on Jesuit Higher Education, 20, 31-38.

25. Leigh, P. (1997). The new spirit at work. Training \& Development, 51(3), 26-33.

26. Lindlof, T. (1995). Qualitative communication research methods. Thousand Oaks, CA: Sage.

27. Lipton, M. (1996). Demystifying the development of an organizational vision. Sloan Management, 37(4), 83-92.

28. Lonsdale, D. (2003). Eyes to see, ears to hear: An introduction to Ignatian spirituality (2nd ed.). Maryknoll, NY: Orbis Books.

29. McCormick, D. W. (1994). Spirituality and management. Journal of Managerial Psychology, 9(6), 5-8.

Communication Studies, Vol. 57, No. 1 (March 2006): pg. 67-85. DOI. This article is @ Taylor \& Francis (Routledge) and permission has been granted for this version to appear in e-Publications@Marquette. Taylor \& Francis (Routledge) does not grant permission for this article to be further copied/distributed or hosted elsewhere without the express permission from Taylor \& Francis (Routledge). 
NOT THE PUBLISHED VERSION; this is the author's final, peer-reviewed manuscript. The published version may be accessed by following the link in the citation at the bottom of the page.

30. Milliman, J., Ferguson, J., Trickett, D., \& Condemi, B. (1999). Spirit and community at Southwest Airlines: An investigation of a spiritual values-based model. Journal of Organizational Change, 12, 221-233.

31. Mitroff, I., \& Denton, E. A. (1999). A study of spirituality in the workplace. Sloan Management Review, 40(4), 83-92.

32. Mooney, D. K. (2002). Do you walk Ignatian? [pamphlet]. Cincinnati, OH: Ignatian Progams/ Mission \& Ministry.

33. Purcell, J. M. (2004, Spring). Branding and Jesuit higher education. Conversations on Jesuit Higher Education, 25, 23-27.

34. Reilly, P. J. (2003, March). Are Catholic colleges leading students astray? The Catholic World Report, 38-46.

35. Rosen, M. (1988). You asked for it: Christmas at the bosses' expense. Journal of Management Studies, 25, 463-480.

36. Rothenbuhler, E. W. (1998). Ritual communication: From everyday conversation to mediated ceremony. Thousand Oaks, CA: Sage Publications.

37. Rothenbuhler, E. W. (2006). Ritual. In G. J. Shepherd, J. St. John, \& T. Striphas (Eds.), Communication as ... Perspectives on theory (pp. 1321). Thousand Oaks, CA: Sage Publications.

38. Sheldrake, P. (2003). Preface to the series. In D. Lonsdale (Ed.), Eyes to see, ears to hear: An introduction to Ignatian spirituality (2nd ed., pp. 9-11). Maryknoll, NY: Orbis Books.

39. Steinfels, P. (2003). A people adrift. New York: Simon \& Schuster.

40. Steinfels, P. (2004, Spring). To the Jesuits: Don't forget you're Catholic. Conversations on Jesuit Higher Education, 25, 22.

41. Stohl, C., \& Cheney, G. (2001). Participatory processes/Paradoxical practices. Management Communication Quarterly, 14, 349-407.

42. Strong, C. (1997). The question we continue to ask: How do organisations define their mission. Journal of Marketing Practice, 3, 268-283.

Communication Studies, Vol. 57, No. 1 (March 2006): pg. 67-85. DOI. This article is @ Taylor \& Francis (Routledge) and permission has been granted for this version to appear in e-Publications@ Marquette. Taylor \& Francis (Routledge) does not grant permission for this article to be further copied/distributed or hosted elsewhere without the express permission from Taylor \& Francis (Routledge). 
NOT THE PUBLISHED VERSION; this is the author's final, peer-reviewed manuscript. The published version may be accessed by following the link in the citation at the bottom of the page.

43. Swales, J. M., \& Rogers, P. S. (1995). Discourse and the projection of corporate culture: The mission statement. Discourse \& Society, 6, 223242.

44. Tracy, K., \& Baratz, S. (1993). Intellectual discussion in the academy of situated discourse. Communication Monographs, 60, 300-320.

45. Tracy, S. (2004). Dialectic, contradiction, or double bind? Analyzing and theorizing employee reactions to organizational tension. Journal of Applied Communication Research, 32, 119-146.

46. Tretheway, A., \& Ashcraft, K. L. (2004). Practicing disorganization: The development of applied perspectives on living with tension. Journal of Applied Communication Research, 32, 81-88.

47. Trice, H., \& Beyer, J. (1985). Studying organizational cultures through rites and ceremonials. Academy of Management Review, 9, 653-669.

48. Turner, P. K. (2004). Mainstreaming alternative medicine: Doing midwifery at the intersection. Qualitative Health Research, 14, 644-662.

Communication Studies, Vol. 57, No. 1 (March 2006): pg. 67-85. DOI. This article is @ Taylor \& Francis (Routledge) and permission has been granted for this version to appear in e-Publications@Marquette. Taylor \& Francis (Routledge) does not grant permission for this article to be further copied/distributed or hosted elsewhere without the express permission from Taylor \& Francis (Routledge) 